\title{
Hormesis of 2,4-D Choline Salt in Biometric Aspects of Cotton
}

\author{
Ricardo F. Marques ${ }^{1}$, Sidnei R. Marchi ${ }^{2}$, Guilherme H. R. Pinheiro ${ }^{1}$, Rodrigo M. Souza ${ }^{2}$, \\ Hildeu F. Assunção ${ }^{1} \&$ Felipe R. Lúcio ${ }^{3}$ \\ ${ }^{1}$ Universidade Federal de Goiás, Regional Jataí, Goiás, Brazil \\ ${ }^{2}$ Universidade Federal de Mato Grosso, Campus Universitário do Araguaia, Barra do Garças, Mato Grosso, \\ Brazil \\ ${ }^{3}$ CORTEVA Agriscience, Brazil \\ Correspondence: Ricardo F. Marques, Universidade Federal de Goiás, Regional Jataí, BR 364, km 195, Jataí, \\ Goiás, Brazil. E-mail: rfmarques94@gmail.com
}

$\begin{array}{lcc}\text { Received: May 18, } 2019 & \text { Accepted: July 3, } 2019 & \text { Online Published: August 15, } 2019 \\ \text { doi:10.5539/jas.v11n13p283 } & \text { URL: https://doi.org/10.5539/jas.v11n13p283 }\end{array}$

The research is financed by Coordination of Higher Education Personnel (CAPES).

\begin{abstract}
Plant hormesis is a phenomenon that involves the presence of toxic compounds at high doses but can be beneficial at low doses. Thus, the aim of this study was to use dose-response curves to assess the effect of hormesis caused by sub-toxic of 2,4-D choline herbicide on biometric variables of cotton plants. The study adopted a completely randomized experimental design with seven replications, and the treatments consisted of nine fractions of the average rate indicated on the 2,4-D choline salt herbicide label: 0 (control); $0.4275 ; 0.855$; $1.71 ; 3.42 ; 8.55 ; 17.1 ; 34.2$ and $68.4 \mathrm{~g}$ ae ha ${ }^{-1}$ applied at phenological stages V4 or B4 of cotton plants. The plants were assessed for the main morphological parameters. The results were subjected to analysis of variance and, when significant, the hormesis model was tested aiming to describe the dose-response curves with low rates stimulation. The maximum hormesis effect for the variables plant height and number of leaves in cotton plants at stage V4 was estimated, in due order, for sub-doses between 1.14 and 3.02 and 1.37 and $5.54 \mathrm{~g}^{2}$ ha $^{-1}$ of 2,4-D choline. The hormesis effect was not significant for total dry matter production when 2,4-D choline was applied at stage V4, irrespective of the year of study. Sub-doses between 0.855 and $1.71 \mathrm{~g}^{2} \mathrm{ee}^{-1}$ of 2,4-D choline salt applied at stage B4 caused hormesis in the height, number of leaves, shoots dry matter and total dry matter of cotton plants.
\end{abstract}

Keywords: Gossypium hirsutum L., hormesis effect, morphology, synthetic auxin

\section{Introduction}

Auxin herbicides were the first class of selective products used to control eudicots in cereal crops. 2,4-D was the first herbicide commercially available having this mechanism of action, being introduced to the market nearly 70 years ago. Since then, herbicides of this class have been discovered and marketed, and, along with this diversification, a broad range of weed control has arisen, increasing the usefulness and importance of this group of herbicides, especially in areas with plants that have been proven to be resistant to other mechanisms of action (Cobb \& Reade, 2010).

There are two basic types of formulations, amine salts and esters (Contiero et al., 2016), and a third, the 2,4-D choline salt that was recently developed and is in the final stages of testing (Skelton et al., 2017). Amines are the most widely used in the world, and the most common are dimethylamines (Contiero et al., 2016). The amine formulations are more water soluble and require hours to traverse the cuticle. Due to this fact, the possible washes after application are less resistant, and they are susceptible to precipitate formation, if applied with water with high cation contents (Foloni, 2016). Despite the improvements with regard to volatilization, there is still uncertainty about the environmental risk of this formulation, due to the extensive and often inadequate use of the active principle (Marcinkowska et al., 2017). 2,4-D choline salt, in turn, provides a reduced potential for off-target movement of physical particles, significantly decreasing the percentage of spray volume with fine 
droplets. In addition to reducing spray drift potential under laboratory conditions, the 2,4-D choline formulation is less volatile than the amine formulations (Manuchehri et al., 2017).

Weeds resistance to herbicides is considered to be a major constraint to global agriculture considering that the number of new resistant biotypes have increased as some management programs have become ineffective. As a result, the interest on the development of resistant crops to the diverse herbicides commercially available has grown. However, development of cotton and soybean cultivars resistant to 2,4-D, for instance, has brought great concerns due to the potential risk of accidental use of this herbicide in nonresistant crops (Blanchett et al., 2017).

2,4-dichlorophenoxyacetic acid (2,4-D) can easily enter the atmosphere by volatilization, spray drift, leaching or runoff, due to its high volatility and water solubility, resulting in potential risks to sensitive crops (Niu et al., 2018). Cotton is considered to be one of the most sensitive crops to 2,4-D, an herbicide that may cause visible symptoms ranging from leaf malformation to severe epinasty and plants death, depending on the environmental conditions, dosage and, especially, on the plant growth stage at the time of exposure (Peterson et al., 2016).

Hormesis is a phenomenon that involves the presence of sub-doses of herbicide applied on plants, as occurring in spray drifts or contamination of spray tanks. Its effect consists of adaptive responses of biological systems to moderate challenges, through which the system improves its functionality and/or tolerance to future challenges even more severe (Calabrese \& Mattson, 2017). As all herbicides act in pathways or processes that are crucial for plants, either in an inhibitory or stimulatory way, low rates of any herbicide may be used to modulate the plant growth, development or composition (Brito et al., 2018).

Auxin-based herbicides, such as 2,4-D, are examples of chemicals that enhance growth at nontoxic concentrations but are lethal at higher rates (Americo et al., 2017). Thus, such responses may be expected with increased auxins production and activity and may interfere with the plants' growth and development (Tavares et al., 2017).

However, studies found in literature did not use dose-response curves to explain observed events that may hinder a correct identification of the hormesis effect (Cedergreen et al., 2005). In addition, the few results found with hormesis in cotton crops used the amine formulation and, therefore, may not represent the future situation of cotton production worldwide, where formulations containing choline salt will be used. Given the above, this work aimed to use dose-response curves to evaluate the effect of hormesis caused by sub-doses of 2,4-D choline salt formulation on biometric variables of non-tolerant herbaceous cotton at different growth stages.

\section{Material and Methods}

The experimental stage of this research was represented by two studies conducted in 2018 and 2019, respectively, in greenhouse conditions. The geographic coordinates were $15^{\circ} 52^{\prime} 29.4^{\prime \prime} \mathrm{S}$ and $52^{\circ} 18^{\prime} 35.1^{\prime \prime} \mathrm{W}$.

The plots consisted of plastic pots with $20 \mathrm{~L}$ of capacity, filled with soil collected from the arable layer of a Humic Distroferric Red-Yellow Latosol. The chemical and physical characteristics of this soil were the following: $\mathrm{pH}$ value in $\mathrm{CaCl}_{2}$ of $4.4 ; 70.0 \mathrm{~g} \mathrm{dm}^{-3}$ of organic matter; nonsignificant values of $\mathrm{P}$ resin; $\mathrm{V} \mathrm{9.5 \% ;} \mathrm{K}$, $\mathrm{Ca}, \mathrm{Mg}$ and $\mathrm{H}+\mathrm{AL}$ contents of $0.21 ; 0.63 ; 0.22$ and 10.0 cmolc dm${ }^{-3}$, respectively; $695 \mathrm{~g} \mathrm{dm}^{-3}$ of sand, $125 \mathrm{~g}$ $\mathrm{dm}^{-3}$ of silt and $180 \mathrm{~g} \mathrm{dm}^{-3}$ of clay. Based on the soil analysis, the fertility and acidity corrections consisted of 3.0 $\mathrm{g} \mathrm{dm}^{-3}$ of dolomitic limestone and $0.35 \mathrm{~g} \mathrm{dm}^{-3}$ of simple superphosphate.

The substrate in the pots was kept moist during the experimental period using automated sprays set to dispense water in an amount similar to the soil field capacity. Minimum, maximum and average daily temperatures inside the greenhouse during 2018 and 2019 are presented in Figure 1. 

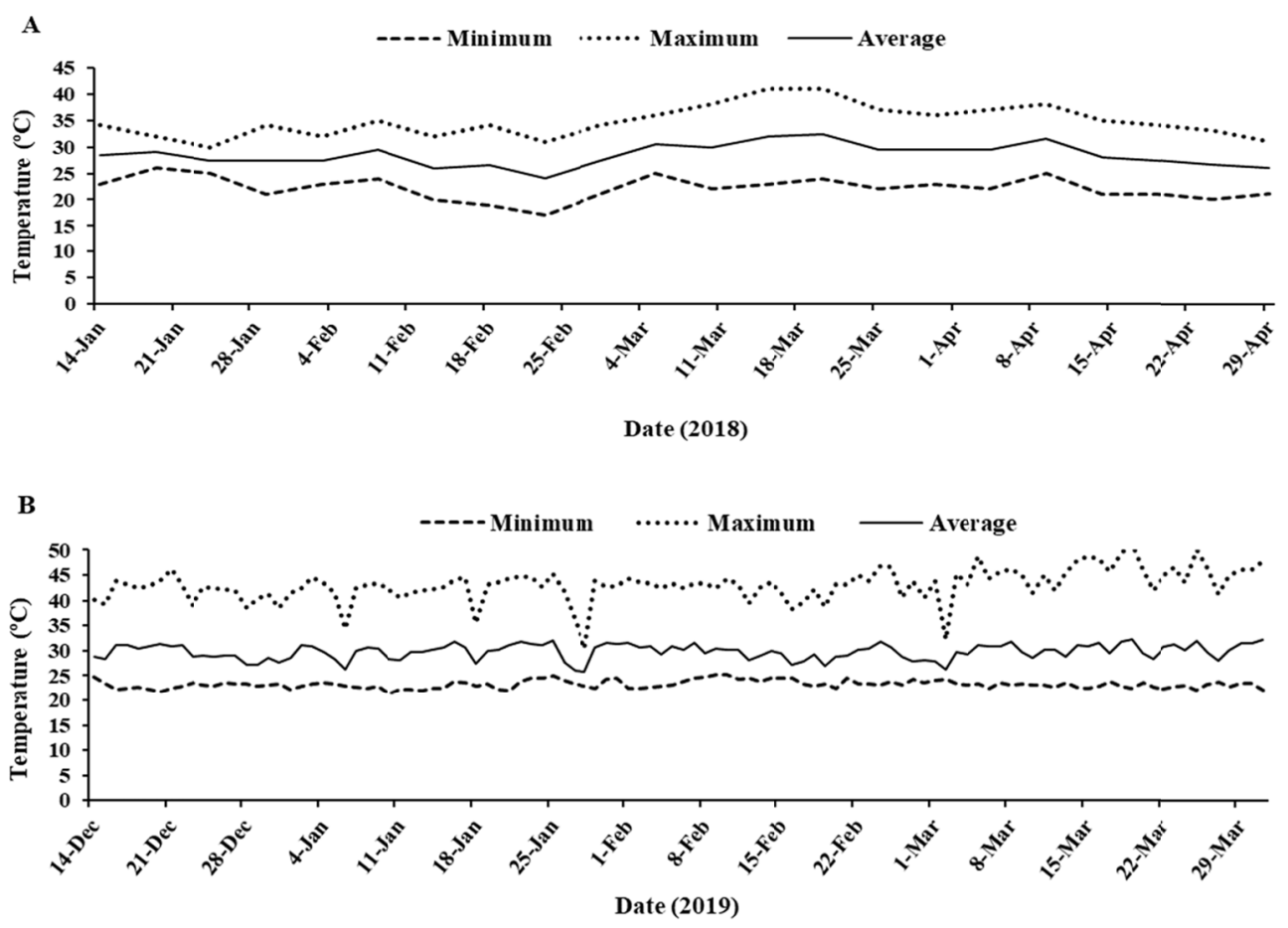

Figure 1. Maximum, minimum and average temperatures as measured in the greenhouse in 2018 (A) and 2019 (B)

Sowing was made at $5.0 \mathrm{~cm}$ deep in an amount sufficient to ensure emergence of approximately three seedlings, and soon after emergence the plants were thinned, so that only one healthy seedling remained in each pot. Seeds of cultivar TMG $47 \mathrm{~B} 2 \mathrm{RF}$, nontolerant to 2,4-D, were used.

The study used a completely randomized design with seven replications, where each pot was considered an experimental unit. The experimental treatments consisted of nine fractions of the average dosage indicated on the label of the 2,4-D choline herbicide ( $684 \mathrm{~g} \mathrm{ae} \mathrm{ha}^{-1}$ ), as follows: 0 (control); $0.4275 ; 0.855 ; 1.71 ; 3.42 ; 8.55 ; 17.1$; 34.2 and $68.4 \mathrm{~g} \mathrm{ae} \mathrm{ha}^{-1}$. The herbicide was sprayed at two different phenological stages of cotton, namely, V4 and B4 (fourth fully developed leaf and first floral button in the fourth reproductive branch, respectively).

The different sub-doses of 2,4-D choline herbicide were applied when a least $50 \%$ of the plants were at the phenological stage corresponding to the object of study, using a $\mathrm{CO}_{2}$-pressurized research sprayer containing a spraying boom with four air-induction nozzles, fan type (AIDA 110015), spaced $50 \mathrm{~cm}$ apart, at a distance of 50 $\mathrm{cm}$ from the target and calibrated at $1.8 \mathrm{kgf} \mathrm{cm}^{-2}$ so as to obtain a liquid volume equivalent to $150 \mathrm{~L} \mathrm{ha}^{-1}$.

The effect of the treatments was determined by observing the visual injury symptoms, at 3, 7, 14, 21 and 30 days of application (DAA), assigning values ranging from 0 (no injury observed) to $100 \%$ (plants death). It is worth mentioning that the visual evaluations at 3, 7, 14 and 21 DAA served as a parameter for assessment at 30 DAA.

The characterization of the cotton plants subjected to application of sub-doses of 2,4-D choline herbicide was carried out at 30 DAA and was determined by the plant height, stem diameter and number of leaves. The plants were then collected and sectioned in shoots and root parts, placed in paper bags and kept in forced circulation oven at $65{ }^{\circ} \mathrm{C}$ during three days, when the samples were weighed in $0.01 \mathrm{~g}$ precision scale for determination of root dry mater, shoots dry matter and total dry matter (root + shoots).

The values obtained for the variables cited were analyzed by the F-test, and the treatments effects were compared by the Scott-Knott test at 5\% probability level, using the statistical program Rbio (Bhering, 2017). When significant, the regression model of Brain and Cousens (1989), adapted by Ritz et al. (2015) was tested for analysis of the hormesis effect aiming to describe the dose-response curves with low rates stimuli:

$$
\mathrm{y}=\mathrm{c}+\frac{\mathrm{d}-\mathrm{c}+\mathrm{fx}}{1+\exp \{\mathrm{b}[\log (\mathrm{x})-\log (\mathrm{e})]\}}
$$

where, $y=$ treatment production; $x=$ herbicide rate; $e=\mathrm{ED} 50$, which is defined as the herbicide rate that provides $50 \%$ of total attainable effect; $d=$ upper limit; $c=$ lower limit; $b=$ indicates the relative slope around $e$; 
$f=$ linear term. The models were then assembled by software R Core Team (2018), and the graphs were plotted by the Origin 8.5.1 SR1 program.

The variables that did not exhibit hormesis were adjusted to the polynomial non-linear regression model using the Origin 8.5.1 SR1 program. To select the regression model, the highest value of the coefficient of determination value $\left(\mathrm{R}^{2}\right)$ at $\mathrm{p} \leq 0.05$ was considered, according to the F-test, considering the biological response.

\section{Results}

The visual injury effects (\%) observed at 30 DAA of 2,4-D choline salt at stage V4 of cotton obtained an exponential and rising behavior in both years of the study, with values above $10 \%$ for rates greater than $1.71 \mathrm{~g}$ ae $\mathrm{ha}^{-1}$ and reaching values close to $95 \%$ of injury when applied at $68.4 \mathrm{~g}$ ae ha ${ }^{-1}$ of herbicide. It is also possible to observe an apparent similarity in the behavior of the trend lines of visual injury values in the years 2018 and 2019 , and due to the sharp shift of the curves direction, it is evident that sub-doses higher than $1.71 \mathrm{~g}$ ae ha ${ }^{-1}$ caused more severe visual injury effects to the cotton plants (Figure 2). It should be noted that the major injuries observed at this stage were branches epinasty and wrinkling of the stem apex and young leaves, especially for the highest sub-doses.
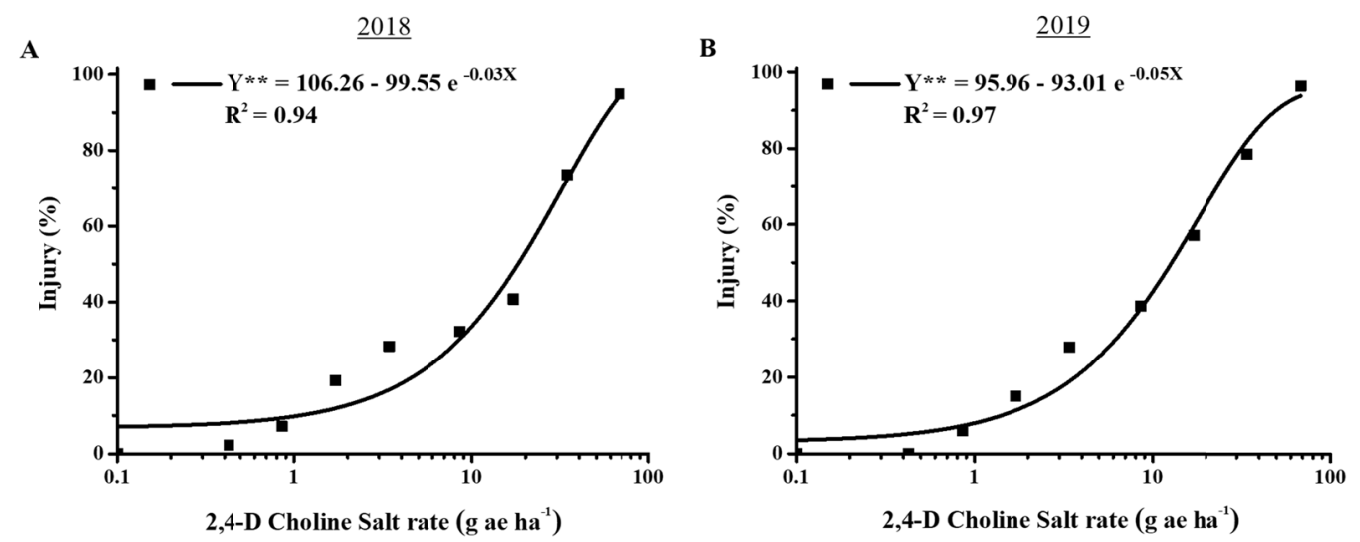

Figure 2. Visual injury (\%) found at 30 DAA caused by sub-doses of 2,4-D choline salt applied at stage V4 of herbaceous cotton plants during 2018 and 2019. ** Significant $(\mathrm{p} \leq 0.01)$

It should be noted that injury levels higher than 15 and $70 \%$ were found 30 DAA for sub-doses higher than 1.71 and $34.2 \mathrm{~g} \mathrm{ae} \mathrm{ha}^{-1}$, respectively. The results found in this study corroborate those by Byrd et al. (2016), who reported that injury percentages higher than 29 and $49 \%$ were observed 14 DAA for rates of 2.0 and $40 \mathrm{~g}^{\text {ae ha }}{ }^{-1}$ of 2,4-D choline salt applied at the growth stage V4 of cotton.

Based on the results found in two years of conduction of this study, it can be seen that sub-doses of 2,4-D choline salt applied at stage V4 of cotton plants may increase the plant height and be conducive to greater leaves production, since the hormesis model was significant for these variables, exhibiting coefficients of determination higher than 0.90 (Table 1; Figure 3). However, it should be noted that even with an increase in these variables, the hormesis effect was not significant for total dry matter production supposedly because of the effects of the herbicide that changed the shape of the leaves and, as a result, the values of root dry matter (RDM), shoots dry matter (SDM) and total dry matter (TDM) were adjusted to the polynomial non-linear regression model, showing high $\mathrm{R}^{2}$ values (Table 1). 
Table 1. $\mathrm{F}$ values, coefficients of determination and coefficients of regression equations for analysis of biometric variables of cotton plants applied with sub-doses of 2,4-D choline salt at stage V4. Maximum estimated growth values and herbicide rate for these values for 2018 and 2019 years

\begin{tabular}{|c|c|c|c|c|c|c|c|c|c|c|}
\hline \multirow{2}{*}{ Variable } & \multirow{2}{*}{ Year } & \multirow{2}{*}{$\mathrm{F}$} & \multirow{2}{*}{$\mathrm{R}^{2}$} & \multicolumn{5}{|c|}{ Parameters of regression with hormesis } & \multicolumn{2}{|c|}{ Max. V. ${ }^{16}$} \\
\hline & & & & $\mathrm{b}$ & $\mathrm{c}$ & $\mathrm{d}$ & $\mathrm{e}$ & f & $\%$ of contr. ${ }^{15}$ & Rate \\
\hline \multirow{2}{*}{ Height $(\mathrm{cm})$} & 2018 & $1107.22 * *$ & 0.99 & 1.34 & -12.68 & 57.60 & 10.31 & 6.30 & 7.95 & 3.02 \\
\hline & 2019 & $155.04 * *$ & 0.95 & 1.82 & 17.39 & 59.12 & 2.15 & 28.19 & 19.16 & 1.14 \\
\hline \multirow{2}{*}{ No. of leaves } & 2018 & $103.36^{* *}$ & 0.92 & 1.75 & -0.06 & 11.96 & 11.95 & 1.23 & 24.41 & 5.54 \\
\hline & 2019 & $92.70 * *$ & 0.91 & 1.74 & 4.88 & 13.44 & 1.57 & 20.72 & 65.56 & 1.37 \\
\hline \multirow{2}{*}{ Variable } & \multirow{2}{*}{ Year } & \multirow{2}{*}{$\mathrm{F}$} & \multirow{2}{*}{$\mathrm{R}^{2}$} & \multicolumn{7}{|c|}{ Parameters of regression without hormesis } \\
\hline & & & & \multicolumn{2}{|l|}{$\mathrm{a}$} & \multicolumn{3}{|c|}{$\mathrm{b}$} & \multirow{2}{*}{\multicolumn{2}{|c|}{$\frac{\mathrm{c}}{-0.0014}$}} \\
\hline \multirow{2}{*}{$\operatorname{RDM}(g)^{1 /}$} & 2018 & $89.01 * *$ & 0.95 & \multicolumn{2}{|l|}{5.39} & \multicolumn{2}{|c|}{0.02} & & & $\frac{\mathrm{c}}{-00014}$ \\
\hline & 2019 & $49.84 * *$ & 0.92 & 5.37 & & \multicolumn{2}{|c|}{-0.16} & & \multicolumn{2}{|l|}{0.0014} \\
\hline \multirow{2}{*}{$\operatorname{SDM}(\mathrm{g})^{1 / 2}$} & 2018 & $64.15 * *$ & 0.94 & 14.07 & & \multicolumn{2}{|c|}{-0.35} & & \multicolumn{2}{|l|}{0.0025} \\
\hline & 2019 & $12.79 * *$ & 0.74 & 11.51 & & \multicolumn{2}{|c|}{-0.41} & & \multicolumn{2}{|l|}{0.0042} \\
\hline \multirow{2}{*}{$\operatorname{TDM}(\mathrm{g})^{/ 3}$} & 2018 & $79.37 * *$ & 0.95 & 19.46 & & \multicolumn{2}{|c|}{-0.32} & & \multicolumn{2}{|l|}{0.0011} \\
\hline & 2019 & $25.52 * *$ & 0.85 & 16.88 & & \multicolumn{2}{|c|}{-0.58} & & \multicolumn{2}{|l|}{0.0056} \\
\hline \multirow{2}{*}{ Diameter $(\mathrm{mm})^{/ 4}$} & 2018 & $73.65 * *$ & 0.94 & 9.36 & & \multicolumn{2}{|c|}{0.04} & & \multicolumn{2}{|l|}{-0.0012} \\
\hline & 2019 & $15.01 * *$ & 0.77 & 9.43 & & \multicolumn{2}{|c|}{-0.16} & & 0.0017 & \\
\hline
\end{tabular}

Note. ${ }^{* *}$ Significant at $1 \%$ probability level. ${ }^{/ 1}$ Root dry matter; ${ }^{/ 2}$ Shoot dry matter; ${ }^{13}$ Total dry matter; ${ }^{14}$ Stem diameter; ${ }^{15} \%$ of control; ${ }^{16}$ Maximum estimated values.

Considering the year 2018, it can be seen that the maximum effect of hormesis for the variables height (Figure 3 A) and number of leaves (Figure $3 \mathrm{~B}$ ) of cotton plants at stage V4 was estimated, respectively, for sub-doses 3.02 and $5.54 \mathrm{~g}$ ae ha ${ }^{-1}$ of 2,4-D choline salt herbicide, with an increase of 7.95 and $24.41 \%$ compared to the control, respectively (Table 1). On the other hand, it could be seen in 2019 that lower sub-doses $(1.14$ and $1.37 \mathrm{~g}$ ae ha ${ }^{-1}$ ) provided higher increases (19.16 and $65.56 \%$ ) for the respective height and number of leaves (Table 1; Figure 3).

This difference between the years is more noticeable in Figure 3, considering that the trend curves obtained for 2019 for these variables stand out in relation to 2018. This difference was supposed to have occurred due to the climatic variations between the years of the experiment (Figure 1), which could directly affect the herbicide behavior in the plants. It is also clear that sub-doses above the cited values diminished the variables height and number of leaves, making it clear the effect of 2,4-D choline salt.
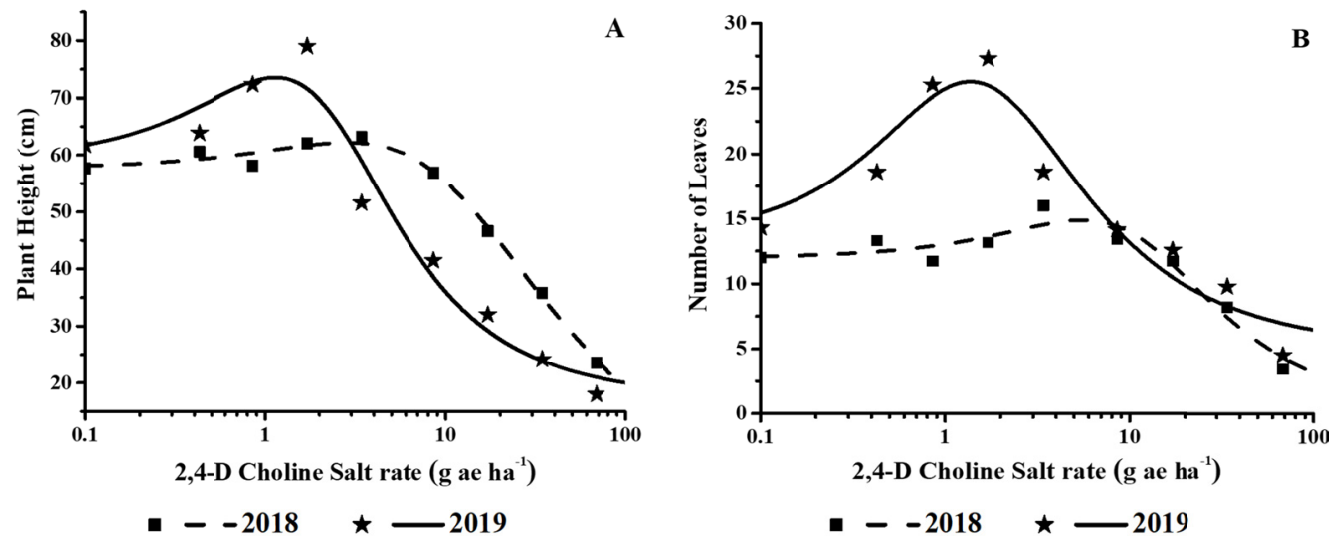

Figure 3. Curves representing height (A) and number of leaves (B) of cotton plants sprayed with sub-doses of 2,4-D choline salt at growth stage V4 in the years 2018 and 2019

For the respective years of study of this experiment, the visual injury effects (\%) were over $20 \%$ at 30 DAA from the rate of $3.42 \mathrm{~g} \mathrm{ae} \mathrm{ha}^{-1}$, exhibiting an exponential and rising behavior up to $90 \%$ of injury when $68.4 \mathrm{~g}$ ae ha ${ }^{-1}$ of herbicide was applied at stage B4 of the cotton plant (Figure 4). The main visible injuries observed at this 
stage were epinasty of the leaf petiole, purplish leaf spots, leaf dryness and death of the stem apex, especially at higher rates. According to Yamashita et al. (2013), toxicity of 2,4-D may vary in plants, from mild leaf epinasty, followed by deformation, to plant death.
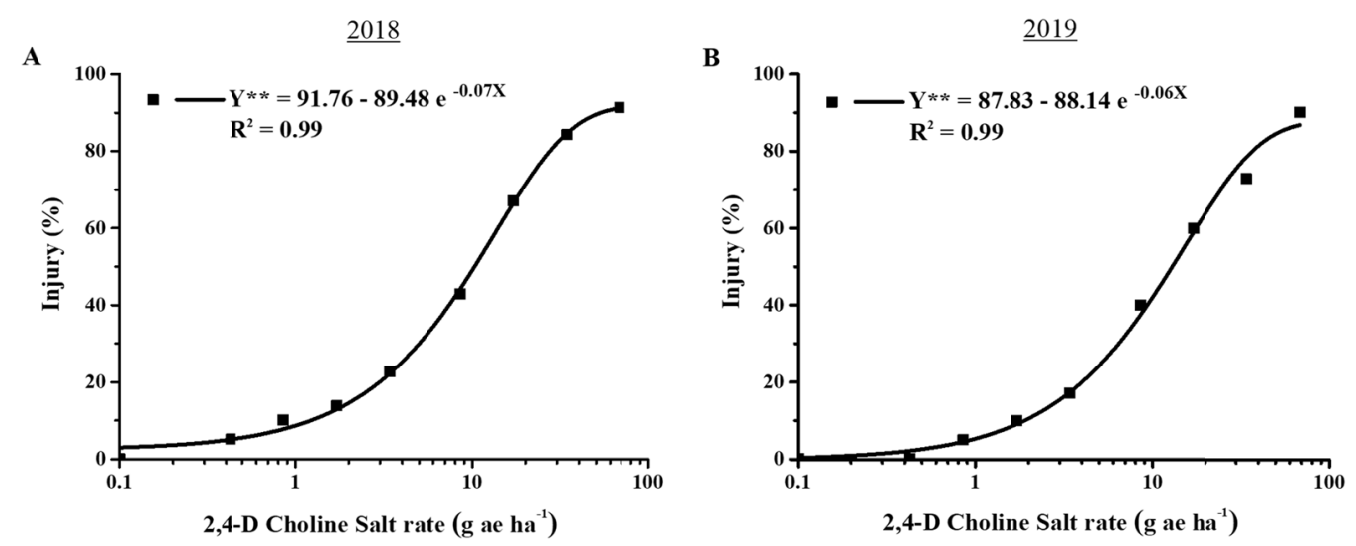

Figure 4. Visual injury (\%) at 30 DAA caused by sub-doses of 2,4-D choline herbicide applied at growth stage B4 of herbaceous cotton plants in 2018 and 2019. ** Significant $(\mathrm{p} \leq 0.01)$

Considering the year 2018 alone, it can be seen that sub-doses of 2,4-D choline herbicide applied at stage B4 of cotton crop may increase plant height and be conducive to a greater production of leaves, SDM and TDM, considering that the hormesis model was significant for these variables, with coefficients of determination of 0.97; 0.96; 0.95 and 0.97, respectively (Table 2; Figure 5).

However, it was found that the hormesis effect was not significant for RDM production and stem diameter, and, therefore, the values were adjusted to the polynomial nonlinear regression model (Table 2). According to Velini et al. (2008), to observe the hormesis effect on roots it is necessary a longer cultivation time, considering that in their study they used glyphosate herbicide and found an increase of the root system in Eucalyptus and Pinus plants that were cultivated for a longer time (60 days), and there was no increase in soybean and corn plants that were cultivated in a shorter period of time (30 days).

For 2019, it was possible to observe that sub-doses of 2,4-D choline applied at stage B4 of cotton plants may increase the plant height and induce more production of SDM and TDM, with a significant adjustment of the hormesis model for these variables and coefficients of determination over 0.90 (Table 2).

However, there was no significance of this model which considers low-rate stimuli for the variables number of leaves and RDM. It should also be noted that no model was adjusted for the variable stem diameter, considering that there was no significant difference between the sub-doses tested and the control not treated with 2,4-D choline (Table 2). 
Table 2. F values, coefficients of determination and coefficients of regression equations for analysis of biometric variables of cotton plants applied with sub-doses of 2,4-D choline salt at stage B4. Maximum estimated growth values and herbicide rate for these values for years 2018 and 2019

\begin{tabular}{|c|c|c|c|c|c|c|c|c|c|c|}
\hline \multirow{2}{*}{ Variable } & \multirow{2}{*}{ Year } & \multirow{2}{*}{$\mathrm{F}$} & \multirow{2}{*}{$\mathrm{R}^{2}$} & \multicolumn{5}{|c|}{ Parameters of regression with hormesis } & \multicolumn{2}{|c|}{ Max. V. ${ }^{16}$} \\
\hline & & & & $\mathrm{b}$ & $\mathrm{c}$ & $\mathrm{d}$ & $\mathrm{e}$ & $\mathrm{f}$ & $\%$ of contr. ${ }^{15}$ & Rate \\
\hline \multirow{2}{*}{ Height $(\mathrm{cm})$} & 2018 & $359.09 * *$ & 0.97 & 1.26 & 29.03 & 60.23 & 5.85 & 4.79 & 1.71 & 1.35 \\
\hline & 2019 & $1042.44 * *$ & 0.99 & 1.50 & 30.45 & 69.78 & 3.35 & 11.79 & 5.27 & 1.20 \\
\hline No. of leaves & 2018 & $197.31 * *$ & 0.96 & 1.28 & -5.43 & 17.20 & 3.55 & 7.84 & 15.33 & 1.90 \\
\hline \multirow{2}{*}{$\operatorname{SDM}(g)^{1 / 2}$} & 2018 & $186.51 * *$ & 0.95 & 1.11 & -33.08 & 26.89 & 2.08 & 30.67 & 6.67 & 0.93 \\
\hline & 2019 & $76.84 * *$ & 0.90 & 1.91 & 6.71 & 16.57 & 2.58 & 5.79 & 19.21 & 1.39 \\
\hline \multirow{2}{*}{$\operatorname{TDM}(\mathrm{g})^{1 / 3}$} & 2018 & $319.87 * *$ & 0.97 & 1.10 & -51.79 & 39.41 & 2.78 & 33.30 & 4.53 & 0.92 \\
\hline & 2019 & $309.84 * *$ & 0.97 & 1.78 & 10.38 & 28.78 & 3.12 & 6.81 & 11.86 & 1.38 \\
\hline \multirow{2}{*}{ Variable } & \multirow{2}{*}{ Year } & \multirow{2}{*}{$\mathrm{F}$} & \multirow{2}{*}{$\mathrm{R}^{2}$} & \multicolumn{7}{|c|}{ Parameters of regression without hormesis } \\
\hline & & & & \multicolumn{2}{|l|}{$\mathrm{a}$} & \multicolumn{2}{|c|}{$\mathrm{b}$} & & \multicolumn{2}{|l|}{$\mathrm{c}$} \\
\hline No. of leaves & 2019 & $11.66^{* *}$ & 0.72 & \multicolumn{2}{|l|}{17.59} & \multicolumn{2}{|c|}{-0.39} & & \multicolumn{2}{|l|}{0.00310} \\
\hline \multirow{2}{*}{$\operatorname{RDM}(\mathrm{g})^{/ 1}$} & 2018 & $32.22 * *$ & 0.88 & 12.49 & & \multicolumn{2}{|c|}{-0.19} & & \multicolumn{2}{|l|}{0.00130} \\
\hline & 2019 & $54.39 * *$ & 0.93 & \multicolumn{2}{|l|}{12.55} & \multicolumn{2}{|c|}{-0.34} & & \multicolumn{2}{|l|}{0.00350} \\
\hline \multirow{2}{*}{ Diameter $(\mathrm{mm})^{14}$} & 2018 & $30.96^{* *}$ & 0.88 & 9.68 & & \multicolumn{2}{|c|}{-0.02} & & \multicolumn{2}{|l|}{0.00005} \\
\hline & 2019 & $2.97^{\mathrm{NS}}$ & - & - & & \multicolumn{2}{|c|}{-} & & \multicolumn{2}{|l|}{-} \\
\hline
\end{tabular}

Note. NS: Nonsignificant. ${ }^{* *}$ Significant at $1 \%$ probability; ${ }^{11}$ Root dry matter; ${ }^{2}$ Shoot dry matter; ${ }^{13}$ Total dry matter; ${ }^{/ 4}$ Stem diameter; ${ }^{15} \%$ of control; ${ }^{/ 6}$ Maximum values.

For year 2018, it was found that the greatest stimuli for the variables relating to plant height (Figure 5A), number of leaves (Figure 5B), shoots dry matter (Figure 5C) and total dry matter (Figure D) of cotton plants applied with sub-doses of 2,4-D choline salt at stage B4 were estimated for the respective rates $1.35 ; 1.90 ; 0.93$ and $0.92 \mathrm{~g}$ ae $\mathrm{ha}^{-1}$ of herbicide, exhibiting an increase of $1.71 ; 15.33 ; 6.67$ and $4.53 \%$, respectively, compared to the control (Table 2; Figure 5).

Regarding 2019, it could be seen that sub-doses of $1.20 ; 1.39$ and $1.38 \mathrm{~g}$ ae ha ${ }^{-1}$ provided higher increases compared to the control $(5.27 ; 19.21$ and $11.86 \%$ ) for height (Figure 5A), shoots dry matter (Figure 5C) and total dry matter (Figure 5D) (Table 1; Figure 3). 

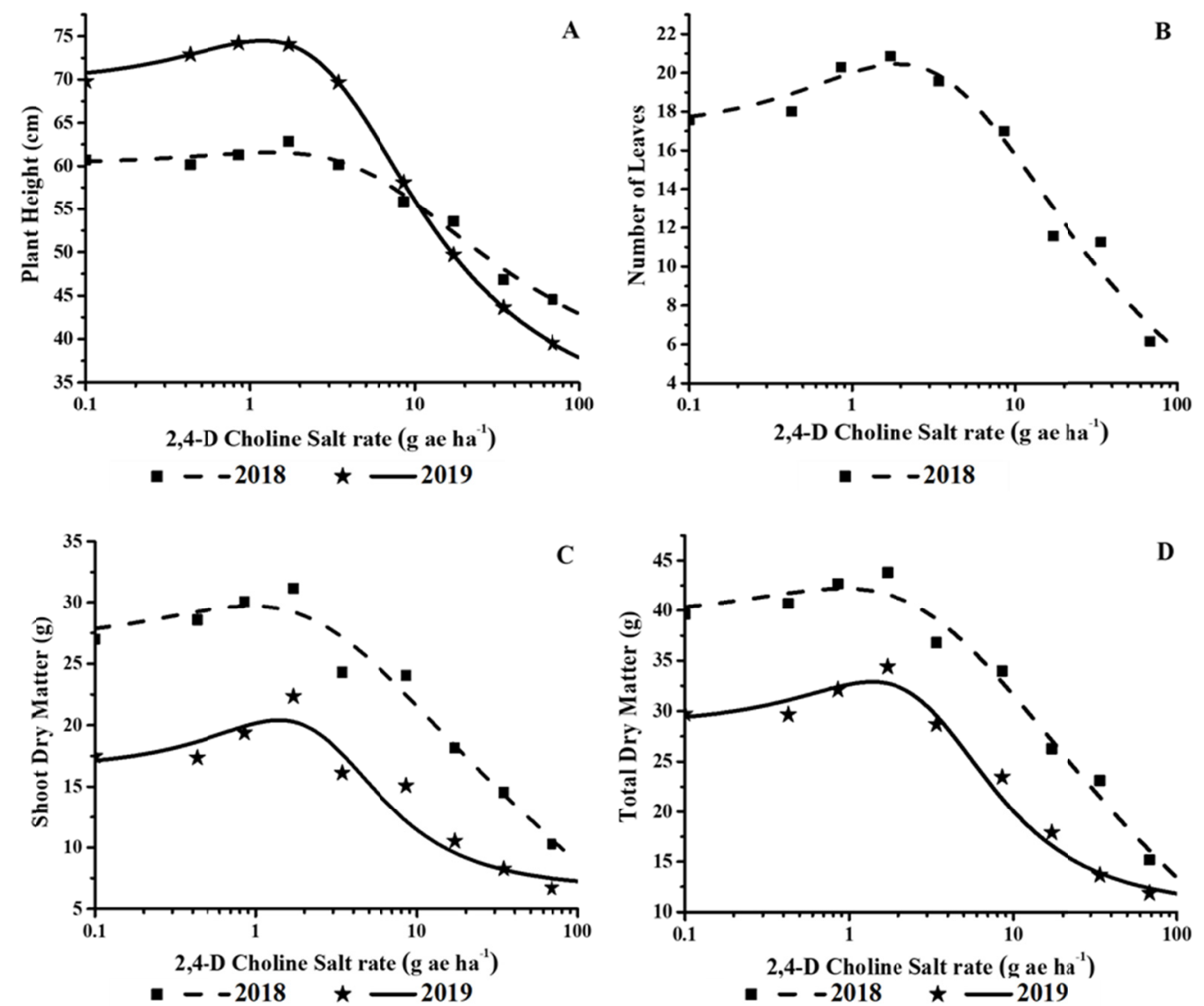

Figure 5. Curves representing the plant height (A), number of leaves (B), shoots dry matter (C) and total dry matter (D) of cotton applied with sub-doses of 2,4-D choline salt at stage B4 in 2018 and 2019

\section{Discussion}

The injury data of this research indicate that cotton plants present greater sensitivity to 2,4-D choline when contaminations occur at the early stages of the crop development. It can be seen for instance, that when $1.71 \mathrm{~g}$ ae $\mathrm{ha}^{-1}$ of this herbicide was applied at the stage V4, visual injury was estimated to be around $15 \%$ at 30 DAA (Figure 2), while for stage B4 this value did not exceed 10\% (Figure 4). However, irrespective of the phenological stage, the injury effects increased considerably as sub-doses of the herbicide increased. Byrd et al. (2016) comment that, as it has been widely known since the discovery of 2,4-D, cotton plants are very sensitive to this herbicide, especially during the vegetative stages, and from the pre-flowering stages (flower buds) sensitivity decreases because leaves are well developed.

Because it is an herbicide of the auxin mimic class and all auxins are weak acids, the molecular formula and the ability to penetrate the cell membrane are related to and $\mathrm{pH}$ dependent. The apoplastic $\mathrm{pH}$ value in plants is around 5.5. At this $\mathrm{pH}$ level, the auxin molecules balance is calculated to be nearly $83 \%$, when dissociated, and $17 \%$ when undissociated (or proton-associated). In this case, the negative charge of the molecule-dissociate carboxylic group will prevent it from traversing the membrane, and only undissociated molecules can cross the plasma membrane by passive diffusion, without the need for assistance of protein carriers. The cytoplasm of vegetable cells, in turn, has a $\mathrm{pH}$ value close to 7.0, making that the balance of auxin molecules shifts almost entirely to undissociated or anionic forms. As the anionic auxins are unable to diffuse across the plasma membrane, they are trapped inside the cells (Zažímalová et al., 2010). Cotton plants at the early growth stage up to the six-leaf stage (V6) are more sensitive to exposure of 2,4-D rates, considering that cotton sensitivity to herbicide can increase due to the reduced vigor of the plant, interfering directly with the passive diffusion of the herbicide, causing damages to the leaf cell walls (Smith et al., 2017).

The results of this study corroborate those found by Egan et al. (2014), who report that cotton plants exhibited low sensitivity to exposure of sub-doses below $1.71 \mathrm{~g}$ ae ha ${ }^{-1}$ of 2,4-D herbicide during the flower bud stages (pre-flowering), with visual injuries of about $9 \%$. However, the plants exhibited higher sensitivity to sub-doses 
between 5.6 and $56.0 \mathrm{~g}$ ae ha ${ }^{-1}$, ranging from 33 to $71 \%$ injury. But the authors comment that there was a great variation in the results found, indicating that visual injury symptoms can only serve as a rough predictor of final yield loss. Everitt and Keeling (2009) add that indeterminate cotton growth allow considerable compensation to stress and such compensation depends on conditions that may vary, even when the injury at early season had been consistent, so it is not a good indicator of effects on the plants' morphology.

As discussed above, one of the main symptoms caused by application of sub-doses of 2,4-D choline in cotton crops at growth stage V4 was wrinkling of the stem apex and young leaves, a symptom also known as "frog's leg". According to Constantin et al. (2007), this symptom is described as typical intoxication caused by 2,4-D herbicide, which occurs especially in new leaves that emerge soon after occurrence of contamination, culminating in the loss of the photosynthetic area and consequent loss of dry mass. In this experiment, it could also be observed that the plants produced a greater number of new deformed leaves, which is presumably due to disordered growth or an attempt to avoid stress caused by application of herbicides sub-doses (Abbas et al. 2016).

It is assumed that the increased plant height and increased leaves production as observed in Table 1 and Figure 3 may have occurred because of the interference of 2,4-D herbicide with cell division and elongation due to the hormonal imbalance that it causes on cells and consequent increase of biosynthesis of ethylene, gibberellins, cytokines and abscisic acid (ABA). This interference leads to abnormal growth of the plant tissue that returns to meristematic activities with inhibition of the cell division into primary meristems (Oliveira, 2011).

However, such disordered growth that supposedly increased the plants height and number of leaves was not significant in the production of larger amounts of total dry matter, making it evident the effect of 2,4-D choline. Damages on most plant tissues treated with 2,4-D are caused by the accumulation of ABA and ethylene, causing oxidative stress induced by high production of reactive oxygen species (ROS). This phenomenon has been described as an effect of high auxin concentrations, leading to an imbalance in the homeostasis of the same and in its interactions with other hormones (Grossmann, 2010).

By altering the plasticity of cell walls, the action of 2,4-D on the structures of the cytoskeleton leads to epinasty of the plant organs as well as to an alteration of the mobility of peroxisomes and mitochondria in the cell environments. As these organelles move along the cytoskeleton, actin disorders probably affect the metabolism of peroxisome and mitochondria, as they share many metabolites with each other and with chloroplasts. Because peroxisomes are antioxidant organelles, their most important function is to remove ROS from different parts of the cell (Rodríguez-Serrano et al., 2014). Considering the effect of auxin herbicides on the actin cytoskeleton and polymerization, the functionality of peroxisomes defense is reduced. Thus, the cell enters a state of severe oxidative stress due to the limitation of peroxisomes and mitochondrial function (Christoffoleti et al., 2015), causing significant losses on the main biometric parameters of sensitive plants, such as cotton, in early development stages.

On the other hand, in this study, it was possible to observe that for herbicide applications at stage B4 of cotton, the increase in the variables height and number of leaves affected the production of total dry matter of cotton plants. This fact shows that the mode of action of 2,4-D depends directly on the herbicide rate and growth stage of the plants, and may cause different symptoms. This underlines the difference between its action as growth promoter or as herbicide. Applications of this herbicide disturb normal growth and cause lethal damages when the plant is at early development stages, irrespective of the herbicide rate. At low concentrations and in later growth stages, 2,4-D stimulates growth and the development processes (Grossmann, 2010).

In this study, it could also be seen that all sub-doses of 2,4-D choline used at stage B4 caused visual injury effects on cotton plants at 30 DAA. Even so, it was found that some sub-doses stimulated the plants to compensate the stress caused, increasing the biometric variables and confirming the hormesis theory for application of sub-doses of 2,4-D choline salt in cotton crops. It should be pointed out that hormesis is considered an adaptive response characterized by initial disturbance of the homeostasis state (Calabrese \& Mattson, 2017). Homeostasis is defined as the subsistence or ability of a system to maintain constant internal environment with effective functions and performances in order to ensure steady physiological conditions during a disturbance (Brito \& Haddad, 2017). When homeostasis is disturbed, hormesis represents an advantage that the body obtains from the resources initially allocated for the activities of repair of an affected tissue, but mildly exceeding what is needed to repair immediate damages caused by the homeostasis disturbance. This process can also readapt the body against damages to a more intense later exposure within a limited period of time, working as a kind of "vaccine" (Ademowo et al., 2019). As a result, the response can perform functions of repair and 
protection against possible subsequent and more intense exposures. But if a later exposure does not happen, the high production of resources for repair is applied in other useful body functions (Cedergreen et al., 2009).

It was also noticed that the increase that resulted from the application of sub-doses between 0.92 and $1.90 \mathrm{~g}$ ae ha $^{-1}$ of 2,4-D choline salt at stage B4 of cotton ranged from 1.71 to $19.21 \%$ compared to the control. Duke et al. (2006) described that in more than thirty cases of plants treated with sublethal rates of herbicide, the maximum rate for hormesis response can be of up to $20 \%$ recommended concentration on label, with responses that can reach about $50 \%$ of increase of the analyzed variable, and the stimuli can be observed in growth characteristics such as gains in weight, height, length, and leaf area and/or internal characteristics such as protein content and sugar levels.

Considering the differences between the results of years 2018 and 2019, Velini et al. (2010) state that, despite the benefit that can be observed, low herbicide rates are not recommended as crop growth stimulant, because the rates that cause the hormesis effect may vary considerably, depending on diverse factors such as cultivar, phenological stage, formulation and, especially, weather conditions.

\section{Conclusions}

Visual injury symptoms (\%) in cotton plants at stage V4 and B4 at 30 DAA had an exponential, upward behavior as increasing sub-doses of 2,4-D choline salt herbicide were applied in both years of study of this experiment.

The maximum hormesis effect for height and number of leaves of cotton plants at stage V4 was estimated, in due order, for 3.02 and $5.54 \mathrm{~g}$ ae ha ${ }^{-1}$ sub-doses of 2,4-D choline, for the experiment conducted in 2018. It could be seen that sub-doses of 1.14 and $1.37 \mathrm{~g}$ ae ha ${ }^{-1}$ provided higher increases for variables height and number of leaves. However, it can be seen that, irrespective of the year, the hormesis effect was not significant for the production of total dry matter.

For 2018, it can be seen that the greatest stimuli for the variables height, number of leaves, shoots dry matter and total dry matter of cotton plants applied with sub-doses of 2,4-D choline at stage B4 were estimated for the respective rates of $1.35 ; 1.90 ; 0.93$ and $0.92 \mathrm{~g} \mathrm{ae} \mathrm{ha}^{-1}$ of this herbicide. In 2019 , it could be seen that the sub-doses corresponding to $1.20 ; 1.39$ and $1.38 \mathrm{~g} \mathrm{ae} \mathrm{ha}^{-1}$ provided more increases compared to the control, for height, shoots dry matter and total dry matter.

\section{Acknowledgements}

The authors are thankful to the Coordination of Higher Education Personnel (CAPES) and CORTEVA Agriscience for the support to this study.

\section{References}

Abbas, T., Nadeem, M.A., Tanveer, A., \& Zohaib, A. (2016). Low doses of fenoxaprop-p-ethyl cause hormesis in littleseed canarygrass and wild oat. Planta Daninha, 34(3), 527-533. https://doi.org/10.1590/s0100-8358 2016340300013

Ademowo, O. S., Dias, H. I., Pararasa, C., \& Griffiths, H. R. (2019). Nutritional Hormesis in a Modern Environment. The Science of Hormesis in Health and Longevity (pp. 75-86). Academic Press. https://doi.org/10.1016/B978-0-12-814253-0.00006-1

Americo, G. H. P., Americo-Pinheiro, J. H. P., \& Furlani Jr., E. (2017). Hormesis Effect of Dichlorophenoxy Acetic Acid Sub-Doses and Mepiquat Chloride on Cotton Plant. Planta Daninha, 35. https://doi.org/ 10.1590/s0100-83582017350100078

Bhering, L. L. (2017). Rbio: A Tool For Biometric And Statistical Analysis Using The R Platform. Crop Breeding and Applied Biotechnology, 17, 187-190. https://doi.org/10.1590/1984-70332017v17n2s29

Blanchett, B. H., Grey, T. L., Prostko, E. P., Vencill, W. K., \& Webster, T. M. (2017). The Effect of 2, 4-Dichlorophenoxyacetic Acid (2, 4-D) on Peanut when Applied During Vegetative Growth Stages. Peanut Science, 44(1), 53-59. https://doi.org/10.3146/PS16-15.1

Brain, P., \& Cousens, R. (1989). An equation to describe dose responses where there is stimulation of growth at low doses. Weed Research, 29(2), 93-96. https://doi.org/10.1111/j.1365-3180.1989.tb00845.x

Brito, I. \& Haddad, H. (2017). A formulação do conceito de homeostase por Walter Cannon. Filosofia e História da Biologia, 12(1), 99-113.

Brito, I. P., Tropaldi, L., Carbonari, C. A., \& Velini, E. D. (2018). Hormetic effects of glyphosate on plants. Pest Management Science, 74(5), 1064-1070. https://doi.org/10.1002/ps.4523 
Byrd, S. A., Collins, G. D., Culpepper, A. S., Dodds, D. M., Edmisten, K. L., Wright, D. L., ... Porter, W. M. (2016). Cotton stage of growth determines sensitivity to 2,4-D. Weed Technology, 30(3), 601-610. https://doi.org/10.1614/WT-D-15-00191.1

Calabrese, E. J., \& Mattson, M. P. (2017). How does hormesis impact biology, toxicology, and medicine? NPJ Aging and Mechanisms of Disease, 3(1), 1-13. https://doi.org/10.1038/s41514-017-0013-z

Cedergreen, N., Felby, C., Porter, J. R., \& Streibig, J. C. (2009). Chemical stress can increase crop yield. Field Crops Research, 114(1), 54-57. https://doi.org/10.1016/j.fcr.2009.07.003

Cedergreen, N., Ritz, J. C., \& Streibig, B. (2005). Improved empirical models describing hormesis. Environment Toxicology Chemical, 24, 3166-3172. https://doi.org/10.1897/05-014R.1

Christoffoleti, P. J., Figueiredo, M. R. A. D., Peres, L. E. P., Nissen, S., \& Gaines, T. (2015). Auxinic herbicides, mechanisms of action, and weed resistance: A look into recent plant science advances. Scientia Agricola, 72(4), 356-362. https://doi.org/10.1590/0103-9016-2014-0360

Cobb, H., \& Reade, J. P. (2010). Herbicide discovery and development. Herbicides and Plant Physiology, 2, 27-49. https://doi.org/10.1002/9781444327793.ch2

Constantin, J., Oliveira Júnior, R. S., Fagliari, J. R., Pagliari, P. H., Arantes, J. G., Cavalieri, S. D., ... Gonçalves, D. (2007). Effect of sub-lethal dosages of 2,4-D on cotton yield and crop susceptibility as a function of its development stage. Engenharia Agrícola, 27, 24-29. https://doi.org/10.1590/S0100-69162007000200004

Contiero, R. L., Biffe, D. F., Constantin, J., Oliveira Jr., R. S., Braz, G. B., Lucio, F. R., \& Schleier III, J. J. (2016). Effects of nozzle types and 2, 4-D formulations on spray deposition. Journal of Environmental Science and Health, Part B, 51(12), 888-893. https://doi.org/10.1080/03601234.2016.1241640

Duke, S. O., Cedergreen, N., Velini, E. D., \& Belz, R. G. (2006). Hormesis: Is it an important factor in herbicide use and allelopathy. New York: Outlooks on Pest Management, 17(1), 29-33. https://doi.org/10.1564/ $16 \mathrm{feb} 10$

Egan, J. F., Barlow, K. M., \& Mortensen, D. A. (2014). A meta-analysis on the effects of 2,4-D and dicamba drift on soybean and cotton. Weed Sciences, 62, 193-206. https://doi.org/10.1614/WS-D-13-00025.1

Everitt, J. D., \& Keeling, J. W. (2009). Cotton growth and yield response to simulated 2, 4-D and dicamba drift. Weed Technology, 23(4), 503-506. https://doi.org/10.1614/WT-08-061.1

Foloni, L. L. (2016). O herbicida 2,4-D: Uma visão geral (1st ed., p. 252). Ribeirão Preto, Brazil: Labcom Total.

Grossmann, K. (2010). Auxin herbicides: Current status of mechanism and mode of action. Pest Management Science, 66(2), 113-120. https://doi.org/10.1002/ps.1860

Manuchehri, M. R., Dotray, P. A., \& Keeling, J. W. (2017). Enlist TM Weed Control Systems for Palmer Amaranth (Amaranthus palmeri) Management in Texas High Plains Cotton. Weed Technology, 31(6), 793-798. https://doi.org/10.1017/wet.2017.55

Marcinkowska, K., Praczyk, T., Gawlak, M., Niemczak, M., \& Pernak, J. (2017). Efficacy of herbicidal ionic liquids and choline salt based on 2,4-D. Crop Protection, 98, 85-93. https://doi.org/10.1016/j.cropro. 2017.03.011

Niu, J., Zhang, Z., Tang, J., Tang, G., Yang, J., Wang, W., ... Cao, Y. (2018). Dicationic Ionic Liquids of Herbicide 2,4-Dichlorophenoxyacetic Acid with Reduced Negative Effects on Environment. Journal of Agricultural and Food Chemistry, 66(40), 10362-10368. https://doi.org/10.1021/acs.jafc.8b02584

Oliveira, J. R. R. S. (2011). Mecanismos de ação de herbicidas. Biologia e manejo de plantas daninhas (pp. 141-148).

Peterson, M. A., Mcmaster, S. A., Riechers, D. E., Skelton, J., \& Stahlman, P. W. (2016). 2,4-D past, present, and future: a review. Weed Technology, 30(2), 303-345. https://doi.org/10.1614/WT-D-15-00131.1

R Development Core Team. (2018). R: A Language and Environment for Statistical Computing. Vienna, Austria: $\mathrm{R}$ Foundation for Statistical Computing.

Ritz, C., Baty, F., Streibig, J. C., \& Gerhard, D. (2015). Dose-Response Analysis Using R. PLoS ONE, 10(12). https://doi.org/10.1371/journal.pone.0146021

Rodríguez-Serrano, M., Pazmiño, D. M., Sparkes, I., Rochetti, A., Hawes, C., Romero-Puertas, M. C., \& Sandalio, L. M. (2014). 2,4-Dichlorophenoxyacetic acid promotes S-nitrosylation and oxidation of actin 
affecting cytoskeleton and peroxisomal dynamics. Journal of Experimental Botany, 65(17), 4783-4793. https://doi.org/10.1093/jxb/eru237

Skelton, J. J., Simpson, D. M., Peterson, M. A., \& Riechers, D. E. (2017). Biokinetic Analysis and Metabolic Fate of 2, 4-D in 2, 4-D-Resistant Soybean (Glycine max). Journal of Agricultural and Food Chemistry, 65(29), 5847-5859. https://doi.org/10.1021/acs.jafc.7b00796

Smith, H. C., Ferrell, J. A., Webster, T. M., \& Fernandez, J. V. (2017). Cotton Response to Simulated Auxin Herbicide Drift Using Standard and Ultra-low Carrier Volumes. Weed Technology, 31(1), 1-9. https://doi.org/10.1614/WT-D-16-00101.1

Tavares, C. J., Pereira, L. S., Araújo, A. C. F., Martins, D. A., \& Jakelaitis, A. (2017). Initial growth of Caryocar brasiliense plants afterapplication of 2,4-D. Brazilian Journal of Forest Research/Pesquisa Florestal Brasileira, 37(89), 81-87. https://doi.org/10.4336/2017.pfb.37.89.1280

Velini, E. D., Alves, E., Godoy, M. C., Meschede, D. K., Souza, R. T., \& Duke, S. O. (2008). Glyphosate applied at low doses can stimulate plant growth. Pest Management Science, 64, 489-496. https://doi.org/ $10.1002 /$ ps. 1562

Velini, E. D., Trindade, M. L., Barberis, L. R. M., \& Duke, S. O. (2010). Growth regulation and other secondary effects of herbicides. Weed Science, 58(3), 351-354. https://doi.org/10.1614/WS-D-09-00028.1

Yamashita, O. M., Orsi, J. V. N., Resende, D. D., Mendonça, F. S., Campos, O. R., Massaroto, J. A., ... Alberguini, A. L. (2013). Deriva simulada de herbicidas em mudas de Coffea canephora. Scientia Agraria Paranaensis, 12(2), 148-156. https://doi.org/10.18188/1983-1471/sap.v12n2p148-156

Zažímalová, E., Murphy, A. S., Yang, H., Hoyerová, K., \& Hošek, P. (2010). Auxin transporters-Why so many? Cold Spring Harbor Perspectives in Biology, 2(3). https://doi.org/10.1101/cshperspect.a001552

\section{Copyrights}

Copyright for this article is retained by the author(s), with first publication rights granted to the journal.

This is an open-access article distributed under the terms and conditions of the Creative Commons Attribution license (http://creativecommons.org/licenses/by/4.0/). 